\title{
PILKADA SERENTAK DAN HUKUM POLITIK: KONTROVERSI KEBIJAKAN PEMERINTAH PUSAT TERKAIT PUTUSAN HUKUM PILKADA KABUPATEN, SIMALUNGUN SUMATERA UTARA TAHUN 2015
}

\author{
Ian Pasaribu
}

\begin{abstract}
Abstack
This study examines, analyzes dna discusses Simultaneous elections Politics and Law: controversy Central Government Policies Related Legal Decisions Election District, North Sumatra Simalungun Where the Year 2015. On December 9, 2015 ago in elections Simalungun which is one of five areas was postponed due Regent Amran deputy candidate Sinaga experienced legal permaslahan. This study uses the theory of Elections, the concept of democracy and the electoral law. This study used qualitative methods with qualitative descriptive analysis techniques. The results of this study are Chronologically elections Simalungun, Inconsistency Regulations, Budget Swelling elections, Process Inaugural JR Saragih. Where the conclusions of this research local elections December 9, 2015 simultaneously experiencing the same problem as well as a substantial permasalahn. Registration problems associated pair of candidates is the responsibility of political parties to avoid any single candidate. On the issue of the availability of budget, the government and local governments need to give a strong political will to urgently solve the problem.
\end{abstract}

\section{A. PENDAHULUAN}

Sejak pertama sekali diperkenalkannya pemahaman bahwa demokrasi adalah pemerintahan oleh rakyat, perdebatan mengenai makna dan lingkup demokrasi hampir tidak pernah berhenti, terutama kaitannya dengan pemerintahan dari rakyat, oleh rakyat dan untuk rakyat. Terdapat bermacam-macam istilah demokrasi. Ada yang dinamakan Demokrasi Konstitusional, Demokrasi Rakyat, Demokrasi Sovyet, Demokrasi Pancasila dan sebagainya. Demokrasi yang dianut di Indonesia, yaitu demokrasi berdasarkan Pancasila, masih dalam tahap perkembangan dan mengenai sifat-sifat dan ciri-cirinya terdapat pelbagai tafsiran dan pandangan. Tetapi yang tidak dapat disangkal ialah bahwa beberapa nilai pokok dari demokrasi konstitusional cukup jelas tersirat di dalam Undang-Undang Dasar 1945 yang belum diamandemen. ${ }^{1}$

Demokrasi sendiri diyakini tumbuh dan berkembang dalam peradaban yunani yang dimulai dengan munculnya negara kota (polis). Secara etimologi berasal dari gabungan dua kata yang berasal dari yunani, yakni demos yang berakti rakyat dan kratos/cratein yang berarti pemerintah. Atau secara ringkas demokrasi diartikan sebagai bentuk pemerintahan rakyat. ${ }^{2}$

Perubahan-perubahan ini sebagai konsekuensi logis yang mesti terjadi senada dengan nilai dan prinsip-prinsip dari sistem demokrasi yang telah dipilih Indonesia sebagai pengganti sistem otoritarian melalui gerakan reformasi di tahun 1998. Derasnya arus demokrasi di tahun 1998 telah membawa Indonesia kepada babak baru dalam konteks penyelenggaraan negara yang sesuai dengan nilai dan prinsip sistem demokrasi, pemilihan umum di tahun 1999 yang

\footnotetext{
${ }^{1}$ R. Dahl, Demokrasi dan Para Pengkritiknya, Jakarta : Yayasan Obor Indonesia, 1992, Hal. 57.

${ }^{2}$ Eko Prasetyo, Demokrasi Tidak Untuk Rakyat, Yogyakarta, Ressist Book, 2005, hal. 9.
} 
dilaksanakan melalui asas langsung sebagai awal pertanda implementasi demokrasi dalam aspek hadirnya partisipasi publik dalam menentukan pemimpin. ${ }^{3}$

Salah satu tuntutan reformasi 1998 adalah pelaksanaan otonomi daerah. Tercatat ada 6 tuntutan Reformasi 1998 yaitu Pertama, Adili Soeharto dan kronikroninya. Kedua, Amandemen UUD 1945. Ketiga, Penghapusan dwifungsi ABRI. Keempat, Otonomi daerah yang seluas-luasnya. Kelima, Supremasi hukum dan Keenam, Pemerintahan yang bersih dari Korupsi Kolusi dan Nepotisme (KKN).

Demokratisasi politik di ranah lokal dalam waktu sepuluh tahun ini telah membuat persaingan memperebutkan kekuasaan politik menjadi semakin kuat. Mobilisasi jaringan kekerabatan, etnis dan keagamaan kemudian diciptakan untuk memenangkan persaingan politik tersebut. Setiap pemilihan baik itu gubernur, bupati maupun kepala desa mempertimbangkan keterwakilan etnis dan agama, sehingga power sharing antara kumpulan etnis dominan selalu mewarnai dalam setiap proses pemilihan kepemimpinan politik. ${ }^{4}$

Desentralisasi kemudian dianggap menjadi salah satu solusi dalam menyelesaikan permasalahan yang ada di daerah. Tujuan utama desentralisasi adalah mengurangi beban pemerintah pusat dalam menangani urusan domestik sehingga terfokus merespon berbagai kecenderungan global dan berkonsentrasi pada perumusan kebijakan makro nasional yang lebih strategis. Desentralisasi juga bertujuan agar pemerintah daerah mengalami proses pemberdayaan yang signifikan dan bertanggung jawab dengan tidak lagi dibawah dominasi pemerintah pusat. Pemerintah pusat hanya berperan melakukan supervisi, memantau, mengawasi dan mengevaluasi pelaksanaan otonomi daerah. ${ }^{5}$

Sebagai koreksi terhadap kegagalan sistem sentralisasi dan uniformisasi pemerintah pusat dengan keluarnya kebijakan desentralisasi untuk otonomi daerah yang dalam visi otonomi daerah yakni dibidang politik, ekonomi, sosial budaya. Untuk bidang politik, karena otonomi daerah adalah buah dari kebijakan desentralisasi dan demokratisasi, maka harus dipahami sebagai sebuah proses untuk membuka ruang bagi lahirnya kepala daerah yang dipilih secara demokratis, memungkinkan penyelenggaraan pemerintahan yang responsif terhadap kepentingan masyarakat dan memelihara suatu mekanisme pengambilan keputusan yang taat pada azas pertanggungjawaban publik. ${ }^{6}$

Pertimbangan-pertimbangan unsur suku sebagai hal yang dipertimbangkan di daerah yang masyarakatnya cukup majemuk dan sering dilanda oleh dinamika sosial, fenomena politik identitas dan keterwakilan politik yang berasas pada etnis dan agama dalam proses politik. Lahirnya gerakan reformasi pada tahun 1998, membawa dampak yang sangat luas dalam tata kehidupan dan penyelenggaraan pemerintahan yang ada. Pada masa Orde Baru, penyelenggaraan pemerintahan berjalan hanya semata-mata mengikuti kehendak penguasa dengan menjadikan birokrasi kekuasaan di pusat-pusat pemerintahan sebagai ujung tombak utama dengan mengabaikan berbagai potensi yang ada di masing-masing daerah.

Dampak langsung dari penyelenggaraan pemerintahan tersebut adalah semakin seragam potensi dan kepentingan daerah yang ada. Pada tahun 2004 DPR mensahkan undnag-undang tentang pemilihan langsung kepala daerah melalui UU No 32 Tahun

\footnotetext{
${ }^{3}$ Robeth Dahl., OP., Cit.,hal.58.

${ }^{4}$ Bagir Manan. 2004. Menyongsong Fajar Otonomi Daerah,FH UII Press, Yogyakarta. Hal.25.

${ }^{5}$ Donni Edwin dkk. 2005. Pilkada Langsung Demokratisasi Daerah dan Mitos Good Governance, Pusat Kajian Politik, Departemen Ilmu Politik Universitas Indonesia, Jakarta. Hal.6.

${ }^{6}$ Ryaas Rasyid. 2005. Desentralisasi dan Otonomi Daerah, Jakarta: LIPI Press. Hal.8-9.
} 
2004. Berlakunya Undang-Undang Nomor 32 Tahun 2004, peserta pilkada adalah pasangan calon yang diusulkan oleh partai politik atau gabungan partai politik. Kemudian ketentuan perubahan terdapat di Undang-Undang Nomor 12 Tahun 2008 yang menyatakan bahwa peserta pilkada juga dapat berasal dari pasangan calon perseorangan yang didukung oleh sejumlah orang. Undang-undang ini menindaklanjuti keputusan Mahkamah Konstitusi yang membatalkan beberapa pasal menyangkut peserta Pilkada dalam Undang-Undang Nomor 32 Tahun 2004.

Dalam perjalannya, Indonesia Setelah 10 tahun melaksanakan pilkada langsung. Pada tahun 2014 DPR di Senayan mensahkan UU Pilkada yang salah satu susbtansinya pemilihan kepala daerah dilakukan oleh DPRD Provinsi dan Kabupaten/Kota. Namun, terjadi gejolak di masyarakat yang membuat Presiden Susilo Bambang Yudhoyono pada tanggalo 2 Oktober 2014 menerbitkan Perppu nomor 1 tahun 2014 yang membatalkan Undangundang nomor 22 tahun 2013 tentang Pemilihan Kepala Daerah, dan Perppu nomor 2 tahun 2014 yang merevisi Undang-undang nomor 23 tahun 2014 tentang Pemerintahan Daerah. ${ }^{7}$

Selanjutnya Presiden Joko Widodo telah menandatangani UU nomor 8 tahun 2015 tentang Undang-Undang tentang Pemilihan Gubernur, Bupati dan Wali Kota. Dalam UU Nomor 8 tahun 2015, pelaksaanan pemilihan gubernur, bupati, dan wali kota dilaksanakan setiap lima tahun sekali secara serentak. Dimana tahap pertama akan dilangsungkan pada tahun 2015 dan tahap kedua pada tahun 2017.

Upaya untuk mewujudkan de-mokratisasi di Indonesia ditempuh melalui berbagai cara, salah satunya adalah dengan menjalankan desen-tralisasi, termasuk di dalamnya Pil-kada langsung. Desentralisasi meru-pakan bagian dari proses demok-ratisasi. Dengan desentralisasi maka kepada daerah, baik pemerintahan-nya, rakyatnya, maupun wakil-wakil rakyat, diberi kemungkinan dan kesempatan untuk memformulasikan dan mengimplementasikan kebijakan publik yang sesuai dengan kepen-tingan masyarakat setempat. Pilkada langsung meru-pakan salah satu bentuk imple-mentasi desentralisasi dalam perspek-tif politik, dimana terjadi proses transfer lokus kekuasaan dari pusat ke daerah. ${ }^{8}$

Pemilihan kepala daerah secara langsung di Indonesia dimulai pada tahun 2005, tepatnya pada bulan Juni 2005. Pilkada langsung di Indonesia sering dikatakan sebagai suatu lom-patan demokrasi yang dapat berkono-tasi positif maupun negatif. Dalam arti positif, Pilkada langsung memberikan kesempatan kepada rakyat di daerah sebagai salah satu infrastruktur politik untuk me-milih kepala daerahnya secara langsung melalui mekanisme pemungutan suara. Hal ini akan mendorong terjadinya keseimbangan antara infra-struktur politik dengan suprastruktur politik, karena melalui pilkada lang-sung maka rakyat dapat menentukan jalannya pemerintahan dengan memi-lih pemimpin yang dikehendaki secara bebas dan rahasia.

Meskipun rakyat tidak terlibat secara langsung dalam pengambilan keputusan pemerintahan sehari-hari, namun mereka dapat melakukan kontrol atas jalannya pemerintahan yang sudah mendapat mandat lang-sung dari rakyat. Dengan demikian terjadi mekanisme check and balance yang mendorong dicapainya akunta-bilitas publik dalam penyelenggaraan pemerintahan daerah. Sedangkan, dalam arti negatif, Pilkada langsung sebagai lompatan demokrasi yang merupakan pestanya rakyat daerah, diartikan sebagai kebebasan rakyat untuk berbuat apa saja, termasuk melakukan tindakan-tindakan anarki dalam pelaksanaan Pilkada serta me-ngambil keuntungan pribadi dari pelaksanaan Pilkada tersebut. ${ }^{9}$

\footnotetext{
${ }^{7}$ Harian Kompas 3 Oktober 2014

http://nasional.kompas.com/read/2014/10/03/09190651/ini.isi.Perppu.Pilkada.yang.Dikeluarkan.Presiden.SBY diunduh pada tanggal 15 maret 2017 pukul 15.14 Wib.

${ }^{8}$ Fitriyah, 2005 'Sistem dan ProsesPilkada Langsung.' Analisis CSIS,Vol. 34, No. 3.

${ }^{9}$ Binoto Nadapdap, 2005. 'Pasang Surut Otonomi Daerah dan Pemilihan Kepala Daerah Secara Langsung.'

Sociae Polites Jurnal Ilmiah Ilmu Sosial dan Ilmu Politik, Vol. V, No. 22.
} 
Menurut Romli (2005), sejalan dengan tujuan desentralisasi dari Smith, Pilkada langsung pada gili-rannya akan memberikan pendidikan politik kepada rakyat di daerah untuk memilih dan menentukan pemimpin-nya sendiri tanpa adanya intervensi dari siapapun, termasuk pemerintah pusat dan/atau elit-elit politik di tingkat pusat. Pilkada langsung juga akan memberikan latihan kepemim-pinan bagi elit-elit lokal untuk mengembangkan kecakapannya da-lam merumuskan dan membuat kebijakan, mengatasi persoalan-persoalan di masyarakat, komunikasi politik dengan masyarakat, serta melakukan artikulasi dan agregasi kepentingan masyarakat. Dari penga-laman-pengalaman inilah pada gili-rannya diharapkan akan dapat dilahirkan politisi-politisi atau pemimpin-pemimpin yang handal yang dapat bersaing di tingkat nasional. ${ }^{10}$

Pilkada serentak juga belum tentu menciptakan pola rekruitmen pimpinan lokal dengan standar yang jelas. Dengan Pilkada langsung maka akan terjadi rekruitmen pimpinan politik yang berasal dari daerah (lokal), bukan didrop dari pusat. Dengan Pilkada langsung, rakyat ikut terlibat secara langsung dalam memilih pemimpin-nya. Keterlibatan rakyat secara lang-sung ini pada gilirannya akan meningkatkan demokratisasi di ting-kat lokal, dimana rakyat benar-benar memiliki kedaulatan. Dengan kata lain tidak terjadi distorsi dalam pelaksanaan kedaulatan rakyat. Pilkada langsung juga dapat menciptakan stabilitas politik dan pemerintahan di tingkat lokal. Hal ini karena kepala daerah yang terpilih memperoleh legitimasi kuat dari rakyat secara langsung, sehingga tindakan penghentian kepala daerah yang dipilih langsung oleh rakyat tidak dapat dilakukan oleh DPRD.

Proses yang berkaitan dengan pilkada serentak tidak lepas dari proses kebijakan. Dimana dalam teori kebijakan Proses kebijakan terkait dengan mekanisme-mekanisme dimana kebijakan publik (pemerintah) dibuat. Pembuatan kebijakan adalah ssebuah proses dalam dua pengertian. Pertama, ia melibatkan serangkaaian aksi atau peristiwa yang saling terkait. Ini dimulai dengan pemunculan gagasan dan pengajuan usulan; dilanjutkan dengan sebagaian bentuk debat, analisis, dan dievaluasi; dan diakhiri dengan pembuatan-pembuatan keputusan-keputuasn formal dan implementasi mereka melalui aksi-aksi yang direncanakan. Pembuatan kebijakan karenanya mirip dengan proses pencernaan dalam tubuh manusia; ia menghubungkan input-input tertentu dengan output-output tertentu. Kedua, ia merupakan sebuah proses dalam penegertiaan bahwa ia membedakan 'bagaiman' tentang pemerintah dari 'apa' tentang pemerintah; yaitu berfokus pada cara di mana kebijakan di buat (proses), dan bukan pada subsatansi dari kebijakan dibuat (proses), dan bukan subtansi dari keijakan itu sendiri dan konsekuensi-konsekuensi (produknya). ${ }^{11}$

Pembuatan keputusan, dan secara spesifik kumpulan keputusan, jelas sangat pokok bagi proses kebijakan. Meskipun pembuatan keputusan juga terkait dengan aksiaksi prakarsa dan implementasi, pembuatan keputusan dan pencapaain kesimpulan biasanya dipandang sebagai ciri pokoknya. Akan tetapi, mungkin sulit untuk menentukan bagaimana dan mengapa keputusan-keputusan dibuat. Keputusankeputusan tidak diragukan lagi dibuat dalam cara-cara yang berbeda oleh individuindividu dan oleh kelompok-kelompok yang berbeda. Didalam badan-badan kecil dan di didalam organisasi-organisasi besar dan didalam struktur-struktur demokrasi

Pilkada serentak dijawalkan pada tanggal 9 Desember 2015 lalu, namun pada tanggal 7 desember 2015 Komisi Pemilihan Umum (KPU) mengumumkan pembatalan Pilkada 5 daerah di Indonesia. Kelima daerah tersebut meliputi Provinsi Kalimantan Tengah, Kabupaten Fakfak, Kota Manado, Kota Pematang Siantar, dan Kabupaten Simalungun. Dari kelima daerah tersebut salah satu permasalahan yang paling unik adalah permasalahan di

\footnotetext{
${ }^{10}$ Romli, Lili. 2005. 'Pilkada Langsung, Otonomi Daerah dan Demokrasi Lokal.' Analisis CSIS, Vol. 34 , No. 3.

${ }^{11}$ Anrew Heywood, 2014, Politik : edisi ke 4, Yogyakarta : Pustaka Pelajar, Hal.621.
} 
Kabupaten Simalungun, Provinsi Sumatera Utara. Kabupaten Simalungun Rabu pada tanggal 10 Februari 2016 sudah menggelar Pilkada.

Titik permasalahan dalam Pilkada Serentak di Kabupaten Simalungun adalah Calon yang sudah di vonis penjara 4 tahun oleh Mahkamah Agung bisa ikut dalam pilkada. Keluarnya putusan Mahkamah Agung (MA) terhadap kasus Amran Sinaga terkait Izin Pemanfaatan Kayu Tanah (IPKTM) di Nagori Mariah Dolok, Kecamatan Dolok Silau Kabupaten Simalungun. Putusan Mahkamah Agung (MA). Salinan putusan Mahkamah Agung tersebut kemudian diteruskan ke Komisi Pemilihan Umum yang kemudian diteruskan ke KPUD Simalungun.

\section{Metode Penelitian}

Penelitian ini menggunakan metode kualitatif. Dimana peneliti mencoba Dengan metode kualitatif, peneliti mengumpulkan data dengan cara deep interview. Kemudian, melalui strategi eksploratoris sekuensial menurut Creswell (2010:22-23), peneliti mengumpulan dan menganalisis data kualitatif dan selanjutnya mengumpulkan dan menganalisis data. Penelitian ini juga menggunakan Paradima Kritis untuk Pilkada Serentak Dan Hukum Politik: Kontoversi Kebijakan Pemerintah Pusat Terkait Putusan Hukum Pilkada Kabupaten, Simalungun Sumatera Utara Tahun 2015.

\section{B. PEMBAHASAN}

\section{Kronologis Pilkada Simalungun}

Kabupaten Simalungun adalah salah satu dari 33 kabupaten/kota di Sumatera Utara. Dimana Secara geografis, Kabupaten Simalungun terletak di antara 2॰36'-3॰18' Lintang Utara dan 98॰32' - 99॰35' Bujur Timur dengan luas wilayah 4.386,60 km atau $6,12 \%$ dari luas keseluruhan Provinsi Sumatera Utara serta berada pada ketingggian 20 - 1.400 m dari atas permukaan laut (rata-rata 3369 m). Kabupaten Simalungun sendiri terdiri dari 33 Kecamatan.

Setelah sempat tertunda selama 2 bulan lamanya sejak 9 Ndesember 2015. Rabu tanggal 10 Februari 2016. Pada akhirnya kabupaten Simalungun menggelar Pilkada. Kabupaten Simalungun merupakan satu dari lima daerah yang pilkadanya terpaksa di tunda oleh KPU karena dianggap bermasalah. Kronologis pembatalan Pilkada Kabupaten Simalungun ini diawali oleh pencoretan pasangan calon JR Saragih dan Amran Sinaga oleh KPUD Simalungun. Penyebabnya adalah keluarnya putusan Mahkamah Agung (MA) terhadap kasus Amran Sinaga terkait Izin Pemanfaatan Kayu Tanah (IPKTM) di Nagori Mariah Dolok, Kecamatan Dolok Silau Kabupaten Simalungun. Putusan Mahkamah Agung (MA) itu menyatakan vonis 4 tahun penjara Amran Sinaga. Salinan putusan Mahkamah Agung tersebut kemudian diteruskan ke Komisi Pemilihan Umum yang kemudian diteruskan ke KPUD Simalungun. KPUD Simalungun pada tanggal 7 Desember 2015, akhirnya menerima salinan putusan pencoretan pasangan calon JR Saragih-Amran Sinaga dan menerbitkan Surat Keputusan Nomor 79/Kpts/KPU-Sim/002.434769/XII/2015 yang menyatakan membatalkan pencalonan JR Saragih-Amran Sinaga pada pilkada serentak 9 Desember 2015.

Namun, pada hari selasa, tanggal 8 Desember 2015. Pihak JR Saragih kemudian merespon cepat putusan yang menganulirnya menjadi Calon Bupati Simalungun dengan memasukkan gugatannya pada Pengadilan Tata Usaha Negara (PTUN) Medan. Di hari yang sama PTUN Medan melakukan persidangan dan mengabulkan gugatan pasangan JR Saragih-Amran Sinaga melalui salinan putusan PTUN Medan Nomor : Nomor 79/Kpts/KPU-Sim/002.434769/XII/2015 yang dalam putusan menyebutkan Memerintahkan KPUD Simalungun untuk menunda keputusan tentang pembatalan 
pasangan calon Bupati dan Wakil bupati Simalungun atas nama JR Saragih-Amran Sinaga sebagai peserta pilkada Simalungun. Akhirnya pada dini hari pada tanggal 9 Desember 2015 Komisi Pemilihan Umum kemudian memutuskan untuk menunda pelaksanaan pemilihan kepala daerah di kabupaten Simalungun. KPUD Simalungun kemudian melakukan banding ke PT.TUN Medan. Selanjutnya, pada tanggal 23 Desember 2015 PT TUN Medan mengeluarkan putusan Nomor 16/G/PILKADA/2015/PT.TUN-MDN yang Mengabulkan sebagian gugatan JR Saragih. Serta tetap menyertakan JR Saragih-Amran Sinaga pada pilkada Kabupaten Simalungun. Tidak terima dengan putusan PT.TUN akhirnya KPUD Simalungun melakukan kasasi ke Mahkamah Agung.

Setelah melalui proses sidang yang panjang pada hari mingu, tanggal 24 Januari 2016. Melalui situs resminya mahkamahagung.go.id pada kolom direktory putusan Mahkamah Agung. Dituliskan bahwa Kasasi yang dimohonkan KPUD kabupaten Simalungun di tolak sepenuhnya. Keputusan tersebut didasarkan pada nota putusan Kasasi Nomor 09 K/TUN/PILKADA/2016. Putusan penolakan gugatan KPUD Simalungun tersebut diputuskan dalam rapat permusyawaratan Mahkamah Agung pada hari rabu, tanggal 20 Januari 2016. Itu Artinya pasangan JR.Saragih-Amran Sinaga tetap ikut menjadi pilkada di kabupaten Simalungun.

Dalam kelanjutannya, KPUD Simalungun akhirnya menetapkan waktu pelaksanaan Pilkada Simalungun pada hari rabu, 10 Februari 2016. Pilkada Simalungun tetap berlangsung dengan 5 pasangan calon. Kelima pasangan calon itu adalah nomor urut 1 Tumpak Siregar-Irwansyah Damanik, nomor urut 2 Evra Damanik-Sugito, nomor urut 3 Nuriyati Damanik-Posman Simarmata, nomor urut 4 JR. Saragih-Amran Sinaga dan nomor urut 5 Lindung Gurning-Soleh Saragih.

Pada Pilkasa Kabupaten Simalungun partisipasi politik yang menggunakan hak pilihnya hanya 52,47\% dari total Daftar Pemilih Tetap (DPT) di Kabupaten Simalungun yang berjumlah 668.355 orang. Artinya ada sekitar 47, 53\% pemilih di Simalungun tidak menggunakan hak pilihnya dengan berbagai alasan. Kemudian pada tangggal 16 maret 2016 melalui Pengumuman KPU Kabupaten Nomor 05/002.434769/III/2016 telah mengumumkan Pemenang Pilkada Kabupaten Simalungun yaitu Pasangan JR saragih-Amran Sinaga.

\section{Inkonsistensi Regulasi.}

\subsection{Tahapan Penentuan Pasangan Calon}

Pada pemilihan kepala daerah di Kabupaten Simalungun menyisakan pertanyaan terkait mekanisme dalam pelolosan pasangan calon dalam pilkada. Misalnya pasangan JR Saragih-Amran Sinaga merupakan calon yang awalnya diloloskan KPUD Simalungun namun pada akhirnya menjelang pemilihan pencalonannya dibatalkan dengan kaeluarnya putusan MA. Tentu tahap pertama mengapa KPUD Simalungun tidak membaca dokumen-dokumen track record calon pasangan calon. Ir. Amran Sinaga telah divonis pidana sesuai dengan Putusan No: 194/K/Pid.Sus/2012 berdasarkan pelanggaran UU No. 26 tahun 2007 pasal 37 ayat (1) jo pasal 37 ayat (7) berbunyi "Bahwa setiap pejabat pemerintah yg berwenang menerbitkan ijin tidak sesuai degan Rencana Tata Ruang sebagaimana dimaksud pada pasal 37 ayat (7) dipidana penjara 5 (lima) tahun denda paling banyak Rp. 500.000.000,-.Selanjutnya atas pelanggaran hukum yang telah dilakukan oleh Ir. Amran Sinaga, maka MA RI telah mengadili terdakwa dan mengabulkan Permohonan Kasasi Jaksa Penuntut Umum pada kejaksaan Simalungun No. 242/Pid.B/2011/PN.Simalungun tanggal 14 Juli 2011 bahwa MA RI menyatakan; 
1. Terdakwa Ir. Amran Sinaga telah terbukti secara sah dan meyakinkan bersalah karena melakukan tindak pidana "dengan sengaja sebagai orang yang melakukan perbuatan sebagai pejabat pemerintah yang berwenang untuk menerbitkan ijin yang tidak sesuai dengan UU tata ruang.

2. Menjatuhkan pidana penjara selama empat tahun terhadap terdakwa.

3. Memerintahkan terdakwa untuk ditahan.

4. Menetapkan barang bukti berupa sembilan lembar asli surat tanda terima ganti rugi dan pelepasan sebidang tanah yang diterbitkan oleh Camat Dolok Silau a.n. Drs. Hendri Sembiring pangkat pembina NIP. $195701031993031001 .^{12}$

KPU kemudian meloloskan pasangan ini hingga ikut dalam Pilkada Kabupaten Simalungun 10 Februari 2016. Kontroversi keikutsertaan Pasangan Jr Saragih-Amran Sinaga secara jelas melanggar UU PKPU 9/2015 Pasal 88 poin (b) yang menyatakan pasangan calon dikenakan sanksi pembatalan sebagai peserta, jika terbukti melakukan tindak pidana kejahatan yang diancam pidana penjara berdasarkan putusan pengadilan yang telah mempunyai kekuatan hukum tetap sebelum hari pemungutan suara.

\subsection{Anggaran Pilkada Membengkak}

Salah satu tujuan pelaksanaan pilkada serentak adalah menekan biaya penyelenggaraan pemilihan gubernur dan bupati/wali kota. Pada tahap I pilkada serentak 9 Desember 2015, dijadwalkan 269 daerah akan memilih kepala daerah, baik provinsi maupun kabupaten/kota, yang masa jabatannya berakhir 2015 hingga Juni 2016. Beda pilkada serentak 2015 dari pilkada sebelumnya, pembiayaan kampanye pilkada sebagaimana diatur Undang- Undang Nomor 8 Tahun 2015 menjadi beban penyelenggara pemilu, bukan peserta. Kenyataannya, tidak semua daerah siap. Data KPU, semula ada 68 dari 269 daerah yang akan melaksanakan pilkada serentak tidak siap dari sisi anggaran. Akibatnya, muncul desakan agar penyelenggaraan pilkada diundur jadi 2016.

Ketidaksiapan daerah banyak dikaitkan dengan keterbatasan ruang fiskal daerah untuk membiayai pilkada sehingga jika dipaksakan harus mengorbankan belanja publik, termasuk untuk pendidikan, kesehatan, dan infrastruktur. Belum lagi siklus anggaran juga tak sesuai dengan siklus tahapan pilkada sehingga dalam APBD tak tersedia anggaran untuk penyelenggaraan pilkada.Sementara pemerintah pusat sejauh ini tetap berpandangan, tidak ada alasan bagi pemerintah daerah untuk tidak siap melaksanakan pilkada serentak. Pemerintah telah menyiapkan payung hukum anggaran pilkada yang memungkinkan daerah menggunakan APBD-P atau Naskah Perjanjian Hibah Daerah untuk pilkada sehingga tak ada alasan bagi daerah tidak menyelenggarakan pilkada. Sanksi juga disiapkan untuk memaksa daerah agar patuh. ${ }^{13}$

Persoalan lain adalah pembengkakan anggaran. Faktanya, efisiensi tak terjadi pada pilkada serentak 2015 ini. Yang terjadi, anggaran pilkada justru membengkak hampir 40 persen dari rencana Rp 5 triliun menjadi Rp 6,89 triliun. Pembengkakan terjadi, antara lain, karena ada biaya kampanye yang harus ditanggung negara dan aji mumpung penyelenggara pemilu yang memasukkan pembelian kendaraan dinas dalam anggaran pilkada (Kompas, 3/6). Terkesan belum ada satu tarikan semangat yang sama untuk menekan ongkos pesta demokrasi yang terlalu mahal selama ini. Penyelenggara pilkada berlomba-lomba mengajukan penambahan anggaran yang seharusnya ditekan. Desember sudah semakin dekat dan masih banyak persoalan yang menjadi pekerjaan

\footnotetext{
${ }^{12}$ Putusan Mahkamah Agung

${ }^{13}$ Harian Kompas tanggal 5 Januari 2016 Hal.12.
} 
rumah besar bagi pemerintah pusat, DPR, pemerintah provisi dan kabupaten/kota, DPRD, KPU, dan KPU daerah dalam mengatasi kendala yang bisa menjadi ganjalan kelancaran penyelenggaraan pemilu serentak 2015. Termasuk di antaranya mengatasi pembengkakan anggaran yang terjadi, dari mana harus ditutup, dan opsi yang disiapkan untuk kondisi terburuk yang mungkin terjadi. Pemerintah pusat dan daerah perlu memperkuat koordinasi dan menyamakan persepsi dalam menyikapi ketidaksiapan daerah dan kendala teknis lain pilkada serentak 2015.

Akibat penundaaan Pilkada kabupaten Simalungun yang tertunda salah satu keruguian adalah DPRD kabupaten Simalungun terpaksa menambah anggran sebesar 31 Milyar rupiah. Dimana sebanyak 15 Milyar untuk kekurangan anggaran sebelumnya. Kemudian pelaksanaan pilkada yang tertunda ada 12 Milyar untuk KPU Simalungun, 1,9 Milyar untuk Polres Kabupaten Simalungun, 1,9 Milyar untuk Panwaslih Simalungun dan 400 juta untuk KodimTentunya apabila KPU bisa jeli melihat persoalan di Kabupaten Simalungun, Dana sebesar itu tidak perlu dikeluarkan. ${ }^{14}$

\section{Proses Gugatan}

Gugagatan ke Mahkamah Konstitusi untuk kemenangan JR Saragih pilkada Simalungun dengan selisih suara berapapun. Baik itu kemenangan dengan 2 persen atau lebih dari 2 persen. Mengingat kasus pilkada yang terjadi di Kabupaten Simalungun sedikit berbeda dengan kasus-kasus pilkada sebelumnya yang hanya secara substansi mensidangkan terkait sengketa di Pilkada saja. Meski, sekalipun menurut undangundang pilkada Pasal 158 UU No. 8 Tahun 2015 tentang Pemilihan Gubernur, Bupati, dan Walikota (UU Pilkada) terkait syarat selisih suara minimal di bawah 2 persen sebagai syarat menggugat hasil pilkada ke Mahkamah Konstitusi.

Meskipun secara substansi ketentuan syarat selisih suara yang termaktub dalam Pasal 158 UU 8/2015 bagi setiap calon kepala daerah untuk yang ingin mengajukan permohonan sengketa MK. Terkesan menafikan tujuan keadilan pemilu itu sendiri, yakni suatu proses sengketa hasil pemilu di MK bukanlah persoalan angka dan hasil semata, tetapi juga keadilan materil.

\section{Proses Pelantikan JR Saragih}

KPUD Simalungun telah mengumumkan pemenang pilkada Kabubaten Simalungun. Proses di mahkamah Konstitusii juga telah selesai namun permasalahan yang terjadi terkait mekanisme pelantikan JR Saragih dan Amran Sinaga pada periode 2016-2022. Sementara menurut PerKPU Penetapan Pemenang pasal 64 Ayat 1 dan 2 Peraturan Penetapan Pilkada,

Pasal 64 (1) Dalam hal sejak diusulkan sampai dengan pengesahan dan pelantikan Pasangan Calon Terpilih berhalangan tetap, KPU Provinsi/KIP atau KPU/KIP Kabupaten/Kota mengusulkan kembali pengesahan dan pelantikan terhadapa calin yang memenuhi syarat dengan melampirkan bukti keterangan berhalangan tetap pada saat pengusulan pengesahan dan pelantikan Pasangan Calon

(2) Dalam hal sejak diusulkan sampai dengan pengesahan dan pelantikan Pasangan Calon terpilih, Pasangan Calon Berhalangan Tetap, KPU Provinsi/KIP atau KPU/KIP Kabupaten/Kota mengusulkan kembali pengesahan dan pelantikan terhadap Pasangan Calon dengan perolehan Suara terbanyak berikutnya dengan melampirkan bukti keterangan berhalangan tetap, Pasangan Calon pada saat pengusulan pengesahan

\footnotetext{
${ }^{14}$ Harian Tribun Medan berjudul Penyelenggara Pemilu Dapat Anggaran Rp 31 Miliar untuk Gelaran Pilkada Simalungun http://medan.tribunnews.com/2016/01/20/penyelenggara-pemilu-dapat-anggaran-rp-31-miliaruntuk-gelaran-pilkada-simalungun diunduh tanggal 6 April 2016 pukul 16.08 wib.
} 
dan Pelantikan Pasangan Calon. Artinya JR Saragih tidak mungkin dilantik sendiri sebagai Bupati Simalungun sebab pada saat pencalonan diusulkan oleh Pasangan calon.

\section{PENUTUP}

Pada Pilkada Kabupaten Simalungun sangat jelas panitera MA membenarkan bahwa Amran Sinaga telah divonis pidana sesuai dengan putusan No: 194/K/Pid.Sus/2012 berdasarkan pelanggaran UU No. 26 Tahun 2007 Pasal 37 Ayat (1) jo Pasal 37 Ayat (7) berbunyi "Bahwa setiap pejabat pemerintah yang berwenang menerbitkan izin tidak sesuai degan rencana tata ruang sebagaimana dimaksud pada Pasal 37 Ayat (7) dipidana penjara lima tahun denda paling banyak Rp500.000.000,-.

Kemudian, atas pelanggaran hukum yang telah dilakukan Amran Sinaga, maka MA telah mengadilinya dan mengabulkan permohonan kasasi jaksa penuntut umum (JPU) pada Kejaksaan Simalungun No. 242/Pid.B/2011/PN. Simalungun tanggal 14 Juli 2011 bahwa MA RI menyatakan:

Pertama, Amran Sinaga telah terbukti secara sah dan meyakinkan bersalah karena melakukan tindak pidana dengan sengaja sebagai orang yang melakukan perbuatan, sebagai pejabat pemerintah yang berwenang untuk menerbitkan izin yang tidak sesuai dengan UU Tata Ruang.

Kedua, menjatuhkan pidana penjara selama empat tahun terhadap terdakwa. Ketiga, memerintahkan terdakwa untuk ditahan. Keempat, menetapkan barang bukti berupa sembilan lembar asli surat tanda terima ganti rugi dan pelepasan sebidang tanah yang diterbitkan oleh Camat Dolok Silau. Tidak hanya untuk Kabupaten simalungun yang bermasalah dengan proses pilkada dari pencalonan, pelaksanaan hingga pengumuman.

Namun, Secara normatif, pilkada serentak 9 Desember 2015 mengalami permaslaahan yang sama karena disamping permasalahn yang substansial. Terkait masalah pendaftaran pasangan calon sudah menjadi tanggung jawab partai politik untuk menghindari adanya calon tunggal. Terkait dengan masalah ketersediaannya anggaran, pemerintah dan pemerintah daerah perlu memberikan kemauan politik yang kuat untuk segera menyelesaikan permasalahan tersebut.

Namun demikian, dalam hal semua upaya tersebut belum juga diselesaikan dalam waktu yang terbatas, pilkada serentak 2015 juga telah diundur terutama untuk pelaksanaan kabupaten Simalungun. Hal ini tentunya bermasalah karena substansi pilkada serentak adalah menjamin penyelenggaraan pilkada yang baik, demokratis dan akuntabel serta mampu menghadirkan pemimpin daerah yang mampu membangun daerah dan meningkatkan kesejahteraan masyarakatnya.

Solusi dalam evaluasi Pilkada Kabupaten Simalungun adalah Evaluasi terhadap regulasi penetapan calon yang akan di Simalungun harus meperhatikan aspek-aspek yang substansial dan tidak berpotensi menyebabkan maslaah di kemudian hari. Dimana solusinya adalah

1. Evaluasi seluruh regulasi yang terkait Pilkada Serentak baik itu Undang-undang, PKPU dan proses penggugatan.

2. KPUD harus selektif terhadap database Calon.

3. Angggaran yang tetap sasaran.

4. Perlunya Lembaga bIndependen diluar KPU dan Panwaslu untuk mengawasi kegiatan pilkada.

5. Pemerintah harus benar-benar siap dalam segia anggaran, kesiapan keamanan, logistik dan lain-lain terkait Pilkada Serentak.

6. Kordinasi antara pemerintah pusat (mendagri), KPU, KPUD dan Pihak-pihak pemangku kepentingan dalam satu komando (pengelolaan satu atap)

Poin-poin diatas merupakan hal yang substansi, mengingat pilkada serentak merupakan kebijakan yang juga akan dilaksanakan pada tahun 2017

\section{D.DAFTAR REFERENSI}




\section{Buku:}

Dahl, Demokrasi dan Para Pengkritiknya, Jakarta : Yayasan Obor Indonesia, 1992. Heywood, Anrew, 2014, Politik : edisi ke 4, Yogyakarta : Pustaka Pelajar.

Manan, Bagir, 2004. Menyongsong Fajar Otonomi Daerah,FH UII Press, Yogyakarta.

Edwin, Donni dkk. 2005. Pilkada Langsung Demokratisasi Daerah dan Mitos Good Governance, Pusat Kajian Politik, Departemen Ilmu Politik Universitas Indonesia, Jakarta.

Prasetyo, Eko , Demokrasi Tidak Untuk Rakyat, Yogyakarta, Ressist Book, 2005.

Rasyid, Ryaas , 2005. Desentralisasi dan Otonomi Daerah, Jakarta: LIPI Press.

\section{Jurnal :}

Fitriyah, 2005 'Sistem dan Proses Pilkada Langsung.' Analisis CSIS,Vol. 34, No. 3.

Nadapdap, Binoto, 2005. 'Pasang Surut Otonomi Daerah dan Pemilihan Kepala Daerah Secara Langsung.' Sociae Polites Jurnal Ilmiah Ilmu Sosial dan Ilmu Politik, Vol. V, No. 22.

Romli, Lili. 2005. 'Pilkada Langsung, Otonomi Daerah dan Demokrasi Lokal.' Analisis CSIS, Vol. 34, No. 3.

\section{Internet :}

Harian Kompas 3 Oktober 2014

http://nasional.kompas.com/read/2014/10/03/09190651/ini.isi.Perppu.Pilkada.yang.Dikeluar kan.Presiden.SBY diunduh pada tanggal 15 maret 2017 pukul 15.14 Wib.

Harian Tribun Medan berjudul Penyelenggara Pemilu Dapat Anggaran Rp 31 Miliar untuk Gelaran Pilkada Simalungun

http://medan.tribunnews.com/2016/01/20/penyelenggara-pemilu-dapat-anggaran-rp-31miliar-untuk-gelaran-pilkada-simalungun diunduh tanggal 6 April 2016 pukul 16.08 wib. 